\title{
Sağlık çalışanlarının çocuklarında depresif belirti sıklığı
}

\author{
Frequency of depressive symptoms in health workers' children
}

\author{
P. Gamze Erten Bucaktepe ${ }^{1}$, Sercan Bulut Çelik ${ }^{2}$, Aysun Tekeli ${ }^{3}$ Coşkun Öztekin ${ }^{4}$, \\ Tahsin Çelepkolu ${ }^{1}$, Vasfiye Demir ${ }^{1}$, Elif Değirmen ${ }^{5}$
}

\section{ÖZET}

Amaç: Bu araştırmada, oldukça ağır ve stresli koşullarda çalışan sağlık personellerinin çocuklarında depresif belirti sıklığı ve sosyodemografik özelliklerle ilişkisinin incelenmesi amaçlanmıştır.

Yöntemler: Tanımlayıcı ve kesitsel tipteki çalışmamız 15 Haziran-17 Temmuz 2014 tarihleri arasında Batman ilinde gerçekleştirilmiş, 6-17 yaş grubunda çocuğu olan, çalışmaya katılmayı kabul eden ve anketleri tam olarak dolduran 106 sağlık personelinin verileri değerlendirilmiştir. Katılımcılar, sosyodemografik veri formunu ve çocukları ile birlikte de çocuk depresyon ölçeğini (ÇDÖ) doldurmuşlardır. Veriler istatistiksel olarak değerlendirilmiştir.

Bulgular: Depresyon ölçeği skorları çocukların biri hariç hepsinde 19 ve üstü olarak tespit edilmiştir $(\% 99,1)$. Çocukların depresyon ölçek skorları ile ebeveynlerin çalıştıkları birim ( $r=0,050, p=0,621)$, nöbet tutma durumları $(r=0,178, p=0,071)$, depresyon öyküleri $(r=0,100$, $p=0,315)$, ailelerin çocuk sayıları $(r=0,001, p=0,994)$, çocukta kronik hastalık varlığı $(r=0,138, p=0,162)$ arasında korelasyon saptanmamıştır. Kadın sağlık çalışanlarının çocuklarının ortalama ölçek skoru daha yüksek olarak tespit edilmiştir $(p=0,027)$.

Sonuç: Sağlık çalışanı çocuklarında skorların yüksek olması oldukça düşündürücüdür ve nedenin multifaktöriyel olabileceği unutulmamalıdır. Bu konuda taramalar yapılarak önlemler almak gerekmektedir.

Anahtar kelimeler: Depresyon, depresif belirti, çocuklar, çocuk depresyon ölçeği

\section{ABSTRACT}

Objective: In this study, we aimed to investigate the relationship between the frequency of depressive signs and the sociodemographic features among the children of health workers who work under harsh conditions and immense stress.

Methods: The descriptive and cross-sectional study was conducted in the Province of Batman, Turkey, between June 15 and July 17, 2014. The study included 106 health workers who had children aged 6-17 years and volunteered to complete the questionnaire. The participants filled out the sociodemographic data form alone and completed the depression scale for children (DSC) together with their children. Data was evaluated statistically.

Results: All but one child had a score of $>19$ on the DSC $(99.1 \%)$. No correlation was found between the scores of the children and the department of their parents $(r=0.050$, $p=0.621)$ and shiftwork $(r=0.178, p=0.071)$, history of depression in their parents $(r=0.100, p=0.315)$, number of siblings in the family $(r=0.001, p=0.994)$, and the presence of chronic diseases in the children $(r=0.138$, $p=0.162)$. The scores were higher in the children of female health workers compared to those of male health workers $(p=0.027)$.

Conclusion: High CDS scores in the children of health workers is a critical issue and the reason for this occurrence may be multifactorial. Further surveys should be conducted to define the measures to be taken.

Key words: Depression, depressive sign, children, depression scale for children

${ }^{\prime}$ Dicle Üniversitesi Tip Fakültesi Aile Hekimliği AD, Diyarbakır, Türkiye

${ }^{2}$ Batman 11 No'lu Aile Sağlı̆̆ Merkezi, Aile Hekimliği, Batman, Türkiye

${ }^{3}$ Elmalı Devlet Hastanesi, Çocuk Hastalıkları Kliniği, Antalya, Türkiye

${ }^{4}$ Atatürk Üniversitesi Tip Fakültesi Aile Hekimliği AD, Erzurum, Türkiye

${ }^{5}$ Batman Bölge Devlet Hastanesi, Biyokimya Bölümü, Türkiye

Yazışma Adresi /Correspondence: Tahsin Çelepkolu,

Dicle Üniversitesi Tıp Fakültesi Aile Hekimliği Anabilim Dalı Sur / Diyarbakır, Türkiye Email: tcelepkolu@gmail.com

Geliş Tarihi / Received: 27.04.2015, Kabul Tarihi / Accepted: 16.06.2015

Copyright (C) Dicle Tıp Dergisi 2015, Her hakkı saklıdır / All rights reserved 


\section{GíRIȘ}

Depresyon, çökkün duygudurum, hayattan zevk alamama, kilo verme, uyku problemleri, değersizlik-suçluluk hisleri, bitkinlik, konsantrasyon güçlüğü, ölüm düşünceleri ile kendini gösteren bir duygudurum bozukluğudur [1]. Depresyon, özellikle çocuk ve adölesanlarda erken tanı ve müdahale gerektiren ciddi bir ruh sağlığı problemi, çevresel ve biyolojik etyolojisi de olan multifaktöriyel bir durumdur [2]. Çocuklarda çökkün duygudurum yerine kolay kızan bir duygudurum, beklenen kilo alımını sağlayamama, aşırı hareketlilik, huysuzluk, oyuna ve arkadaşlara karşı ilgisizlik tanıda göz önünde bulundurulması gereken hususlardır [1]. Geçmişle kıyaslanınca günümüzde değişimlerin daha hızlı yaşanmas1, daha bireysel yaşama, internet bağıml1lığı, yaşam koşullarının zorlaşması, çocukların ilkokuldan başlayarak başarı için sürekli yarış halinde olmaları çocuklarda daha fazla psikolojik sorun görülmesine neden olmaktadır. Bhatia ve Bhatia [3], herhangi bir zaman dilimi içinde çocuk ve adölesanların \%15'e kadarının depresyon semptomları gösterebildiğini, bunun da büyüme ve gelişmeyi, okul başarısını, akran veya aile ilişsilerini olumsuz etkilediği ve intihara neden olabildiğini belirtmektedir. Dünya Sağl1k örgütü (DSÖ) verilerine göre dünyada en az 350 milyon kişi depresyonla yaşamaktadır. Depresyon dünya çapında iş görmezliğin başta gelen nedenlerindendir. Sadece depresyondaki kişiyi değil, etrafındaki sevdiklerini de etkilemektedir. DSÖ, pek çok kişinin bu durumu kabullenemediğinden depresyonun saklı kaldığını, ne tedavi edildiğini ne de bu konuda konuşulduğunu vurgulamakta ve her yıl bir milyon kişinin depresyonu nedeni ile kendi hayatına son verdiğini, intihar eden her bir kişiye karşılık 20 veya daha fazla kişinin de intihar girişiminde bulunduğunu belirtmektedir [4]. Çocukluk çağ 1 depresyonunun psikososyal fonksiyonlara negatif etkisi olduğundan ve ileriki dönemlerde diğer psikiyatrik bozuklukların meydana gelme riskini arttırdığından dolayı erken tanınıp zamanında tedavi edilmesi gerekmektedir $[5,6]$.

Ebeveyn tutumlarının çocuklar üzerindeki etkileri de yadsınamaz. Depresyon, birçok faktörle ilişkili olduğu gibi ailesel (parçalanmış veya kalabalık aile, ebeveyn ölümü, boşanma, genç ebeveyne sahip olma, ailede depresyon öyküsü) etmenlerle de ilişskili olabilmektedir [3,7]. Bebeklikten gençliğe kadar ebeveynleriyle yakın ve sıcak ilişki kurmuş, ebeveynleri tarafindan desteklenen ergenler kendilerine daha güvenli, özsaygıll, kişilerarası iletişim becerili ve daha akademik başarılı olurken; aksi durumda ise incinebilirlik düzeyleri yüksek, düşük özsayg1lı ve depresif ergenler olmaktadırlar $[8,9]$. Bu bağlamda ebeveynlerin çocuklarının davranışsal ve duygusal gelişiminde çok önemli bir yere sahip olduğu söylenebilir [10]. Çetin ve Çok da [11], çocuğun fiziksel ve psikolojik gelişiminde ilk ve en önemli unsurun ailesi olduğunu, ebeveynlerin tutum ve davranışlarının çocukları etkilediğini, özellikle ergenlere net kurallar sunulduğunda, etkinlikleri hakkında sorular sorulduğunda ve ebeveynleri ile daha az çatışma algıladıklarında davranış sorunları, alkol ve madde kullanımının daha az görüldüğünü belirtmektedirler.

Her ne kadar çocukların ebeveynleriyle ilişkisini nicelikten çok nitelik belirlese de ailelerin iş koşulları çocukların duygu durumunu etkileyebilmektedir. Özellikle zor koşullar altında uzun süre çalışmak zorunda kalan ve nöbet, vardiya usulü ile çalışan sağlık personelinin çocukları da ebeveynlerinin bu durumundan etkilenmekte, anne-babalarının stresli çalışma koşulları eve yansıyabilmekte hatta anne-babalarıyla daha az vakit geçirmektedirler. Bu araştırmada, oldukça ağır ve stresli koşullarda çalışan sağlık personellerinin çocuklarında depresif belirti sıklığ ve bu durumun sosyodemografik özelliklerle ilişkisinin incelenmesi amaçlanmıştır.

\section{YÖNTEMLER}

Tanımlayıcı ve kesitsel tipteki çalışmamız 15 Haziran-17 Temmuz 2014 tarihleri arasında Batman ilinde gerçekleştirilmiştir. Çalışmanın etik kurul onayı alınmıștır. İl Sağlık Müdürlüğünden de gerekli izinler alınmış, Batman ilindeki toplam sağlık personeli sayıs1 1219 olarak tespit edilmiştir. Hastane, Aile Sağlı̆̆1 Merkezi (ASM), Toplum Sağlığı Merkezi (TSM), 112 İstasyonlarına gidilerek, gerekli bilgilendirme yapıldıktan sonra sağlık personelleriyle görüşülmüş 6-17 yaş grubunda çocuğu olan 217 personel saptanmıştır. Sağlık personelleri çalışma ve amacı konusunda bilgilendirildikten sonra 133 kişi çalışmaya katılmayı kabul etmiştir. Katılmayı kabul edenlere bilgilendirilmiş onam formu imzalatıldıktan sonra sosyodemografik veri formu ve çocuk depresyon ölçeğinden oluşan anket formları 
dağıtılmış, nasıl doldurulacağ 1 açıklanmış ve veri formunu kendilerinin doldurması, ölçeği çocukları ile birlikte doldurmaları istenmiş, ertesi gün anketlerin alınacağı bildirilmiştir. Tam ve eksiksiz olarak 106 anket elimize ulaşmıştır.

Sosyodemografik veri formunda yaş, cinsiyet, çalışılan birim, meslek grupları, çalışma biçimi ve saatleri, kronik hastalık varlığı, depresyon öyküleri, çocuklarının yaş ve cinsiyeti sorulmuştur. Çocuklar İçin Depresyon Ölçeği (ÇDÖ) ise çocuk-ergen depresyonunu araştırmada kullanılan, 6-17 yaş arası çocuklar için 27 maddeden oluşan bir kendini değerlendirme ölçeğidir. Kovacs [12] tarafından Beck Depresyon Envanteri esas alınarak geliştirilmiş olan bu ölçek Türkçeye Öy [13] tarafindan uyarlanmıştır. Ölçekte çocukluk depresyonuna özgü okul durumu ve arkadaş ilişkileri gibi alanlarla ilgili maddeler de bulunmaktadır. Ölçeğin test geçerliği $(r=0,70)$ ve iç tutarlığ $1(\mathrm{a}=0,80)$ yüksek bulunmuştur. Ölçeğin her maddesinde depresyonla ilgili bir belirtinin son iki hafta içinde varlığ 1 ve şiddetinin sorgulandığ 1 üç ayr1 seçenek (0,1,2 puan şeklinde belirlenmiş) bulunmaktadır. Buna göre her madde 0 ila 2 arasında skorlanır: 0, semptomun olmadığını, 1 hafif semptomlar1, 2 belirgin semptomu gösterir. Maksimum puan 54'tür. On dokuz ve üzeri puan alanlar depresif bozukluk varlığ 1 açısından değerlendirilmektedir.

Araştırma verilerinin istatistiksel değerlendirmesinde SPSS (Statistical Package for Social Sciences) 18,0 for Windows istatistik paket programı kullanılmıştır. Numerik değişkenler ortalama \pm standart sapma (SD) ile, kategorik değişkenler sayı ve yüzde (\%) ile gösterilmiştir. Verilerin normal dağılıma uyup uymadığına Kolmogrov-Smirnov testi ile bakılmıştır. Normal dağılım gösteren ve ortalamaları alınabilen veriler için Bağımsız gruplar-t testi, normal dağılım göstermeyenler için nonparametrik Mann Whitney-U testi; kategorik değişkenlerin karş1laştırmasında Chi-kare testi; parametreler arasındaki ilişkileri belirlemede normal dağılım gösterenlerde Pearson, normal dağılım göstermeyenlerde Spearman rho testi uygulanmıştır. İstatistiksel anlamlı1ık sınırı olarak $\mathrm{p}<0,05$ ve $\% 95$ güven aralığ 1 alınmıştır.

\section{BULGULAR}

$\mathrm{Bu}$ çalışmada Batman ili merkezindeki 6-17 yaş grubu aralığında çocuk sahibi olan ve çalışmaya ka- tılmayı kabul eden 64 kadın $(\% 60,4)$ ile 42 erkek $(\% 39,6)$ olmak üzere toplam 106 sağlık personelinin verileri değerlendirildi. Katılımcıların ortalama

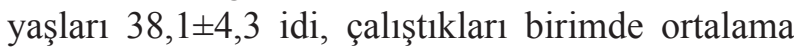
$4,8 \pm 4,9$ y1ldan beri görev yapiyorlard1, haftada ortalama 40,7 $\pm 2,6$ saat çalışıyorlardı ve çocuk sayıları ortalama $2,7 \pm 1,1$ 'di.

Sağlik personelinin 21'i $(\% 19,8)$ doktor, 39'u $(\% 36,8)$ hemşire, 19 'u $(\% 17,9)$ ebe ve 27 'si $(\% 25,5)$ sağlık personeliydi (laborant, teknisyen vs.). Otuz altıs1 $(\% 33,9)$ devlet hastanesi, 33'ü $(\% 31,1)$ toplum sağlı̆̆1 merkezinde, 29'u $(\% 27,4)$ aile sağllğ merkezinde, 4'ü $(\% 3,8)$ KETEM'de ve 4'ü $(\% 3,8)$ de özel hastanede çalışmaktaydı. Katılımcıların çalışma saatleri ile cinsiyetleri ve meslek grupları arasinda fark yoktu (sirasiyla $p=0,095$ ve $p=0,425$ ). On üç kişi nöbet usulü çalışmaktaydı ve nöbet tutanlar daha çok hemşirelerdi $(p=0,015)$. Yirmi birinin kronik bir hastalığ 1 mevcuttu (diabetes mellitus, tiroid hastalıkları, kardiyovasküler sistem hastalıkları vs.). Depresyon tanısını geçmişte veya şimdi almış olan 17 kişi vardı, altısı şu anda ilaç kullanmaktayd1. Eşlerinin yedisinde depresyon öyküsü, 16'sında kronik bir hastalık vard1.

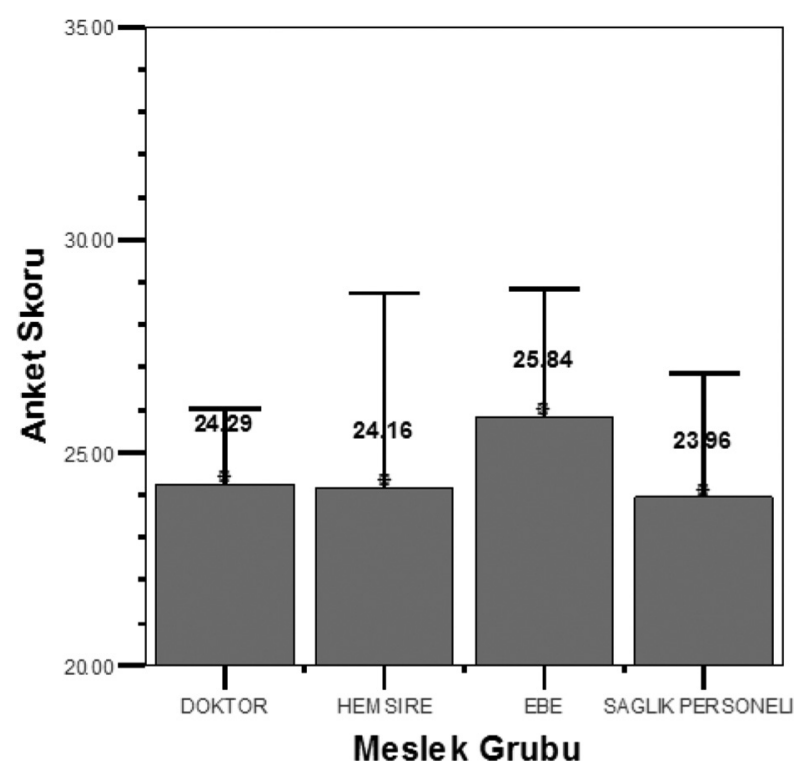

Şekil 1. Meslek gruplarına göre anket skor ortalamaları

Katılımcıların 6-17 yaş grubundaki çocuklarının yaş ortalaması 13,2 $\pm 3,7$ idi, 57'si $(\% 53,8) \mathrm{k} 1 \mathrm{z}$, 49’u $(\% 46,2)$ erkekti. On birinde çoğunluğu alerji, astım olan kronik bir hastalık mevcuttu. Depresyon 
ölçeği skorları biri hariç hepsinde 19 ve üstü olarak tespit edildi $(\% 99,1)$. Skor ortalamaları $24,4 \pm 3,5$ 'ti (\%95 güven aralığ $1=23,9-25,1)$. Skorlarla çocukların cinsiyetleri arasında anlamlı fark yoktu $(p=0,425)$. Kadın sağlık çalışanlarının çocuklarının ortalama ölçek skoru daha yüksek olarak tespit edildi $(\mathrm{p}=0,027)$. Ebeveynlerin meslek grupları ile anket skor sonuçları arasında anlamlı fark bulunma$d_{1}(p=0,294)$ ancak ebelerinki biraz daha yüksekti. Meslek gruplarına göre anket skor ortalamaları Şekil 1'de gösterilmiştir. Çocukların depresyon ölçek skorları ile ebeveynlerin çalıştıkları birim $(\mathrm{r}=0,050$, $\mathrm{p}=0,621)$, nöbet tutma durumlar1 $(\mathrm{r}=0,178$, $\mathrm{p}=0,071)$, depresyon öyküleri $(\mathrm{r}=0,100, \mathrm{p}=0,315)$, ailelerin çocuk sayıları $(\mathrm{r}=0,001, \mathrm{p}=0,994)$, çocukta kronik hastalı varlı̆ $1(\mathrm{r}=0,138, \mathrm{p}=0,162)$ arasında korelasyon saptanmadi.

\section{TARTIŞMA}

Depresif bozuklukların 7-8 yaşından önce çok az görüldüğü, 8 yaşından sonra artmaya başladığı ve ergenlikle yaklaşık iki katına çıktığ dir [14]. Çocuk gelişiminde oyun çağının bitip okul çağının başladığı ve ardından ergenliğin geldiğ 6-17 yaş büyük önem taşır. Bu aynı zamanda ebeveynle ilişkilerin değiştiği, sosyalleşmenin de başladığ1 ve şekillendiği dönem olduğundan özellikle bu dönemdeki çocuklar çalışmaya dahil edilmiştir. Çalışmamızda sağlıkçıların bu yaştaki çocuklarının \%99,1'inde ÇDÖ skorlarının kesim noktasının üstünde bulunması oldukça dikkat çekicidir. Her ne kadar ÇDÖ depresyon tanısını değil de depresif belirti sıklığını ortaya koyuyor olsa da skorların yüksekliği düşündürücüdür. Tanı ancak klinik görüşmeler ve uzman değerlendirilmeleri ile konulabilir. Skorların bu kadar yüksek olmasının nedeni ebeveyn mesleği ile ilgili olabileceği gibi çevresel koşulların, psikososyal faktörlerin de rolü olabilir; bunun için daha ayrıntılı çalışmalar yapmak gerekmektedir. Ebeveynlerin meslek grupları, çalıştıkları birim, nöbet tutma durumları, çocuk sayıları, depresyon öyküleri, çocukta kronik hastalık varlığı ve cinsiyet ile ÇDÖ skorları arasında istatistiksel anlamlılık saptanmaması, fakat kadın sağlık çalışanlarının çocuklarının ortalama ölçek skorunun daha yüksek olarak tespit edilmesi, annelerin işleri ile ilgili faktörlerin çocukların duygu durumunu ne kadar etkilediğini göstermektedir.
Annelerin stresinin çocuğu daha çok etkilediği literatürde de belirtilmektedir [15]. İşten eve taşınan stresin, evdeki atmosferi ve ebeveyn-çocuk ilişkilerini etkilediğini ve böylece çocukların daha küçük yaşlarda stresle tanıştıklarını belirten Heinrich [16], çocukların olumlu psikososyal gelişimi için özellikle annelerin çalışma koşullarının kolaylaştırılması ve çalışma saatlerinin esnekleştirilmesi gerektiğini vurgulamıştır. Ebeveynlerin işleri ile çocukların duygu durumları arasındaki ilişkiyi gösteren direk yayınlar olmamakla beraber ebeveynlerin stresleri, özellikle de işle ilgili olanları yapılan pek çok çalışmada çocukların psikososyal problemleri ile ilişkili bulunmuştur [17-19]. Johnson ve Allen [20] de iş ve çalışma saatlerinden kaynaklanan ebeveyn stresi ile çocukların sağlıkları arasındaki ilişkiyi incelemişler ve oldukça bağlantılı olduğunu bulmuşlardır. İş yükünün aile-iş çatışmasına neden olduğu ve bu durumun bayan çalışanlarda daha belirgin olduğu ülkemizde yapılan çalışmalarla da ortaya konulmuştur [21-22].

Literatürde bizim bulgularımıza yakın tek sonuca İstanbul il merkezindeki çocuk yuvalarında yapılan çalışmada ulaşılmış, 9-13 yaş grubu 132 çocuğa ÇDÖ uygulanmış, \%99,2'sinin kesim puanının üstünde puan aldıkları belirlenmiş ve cinsiyet farkı olmadığı saptanmıştır [23]. Yuvada yaşayan çocuklarda böyle yüksek bir değeri saptamak şaşırtıcı değildir. Ceylan ve ark. [24] 2003 y1lında Batman'a yakın olan Mardin ilinde lise son sınıf öğrencilerinde depresif bulguları \%37 olarak tespit etmişlerdir. Van'da da lise son sınıf öğrencilerinde Beck Depresyon Ölçeği ile depresif semptomlar \%66 olarak ve kız öğrencilerde depresif duygudurum varlığı erkeklerden daha fazla tespit edilmiştir. Depresyon ve anksiyete ölçek puanları arasında pozitif korelasyon saptanmıştır [25]. Erzurum il merkezinde lise öğrencilerinde Beck depresyon Ölçeği kullanılarak yapılan bir çalışmada ise orta ve ağır depresyon düzeyi $\% 47,11$ olarak tespit edilmiş ki buna hafif düzeyler de eklenince oranın $\% 72,73$ 'e ç1ktığ1 görülmüştür. Çalışmada cinsiyet açısından bir fark bulunmazken oran lise son sinifta daha yüksek bulunmuştur [26]. Çalışmamızdaki ile paralel olarak doğu illerinde yaşayan çocuklarda depresif belirtilerin yüksek olarak saptanması o illerdeki sosyal ortam yetersizliğinden, ailelerin daha baskıcı tutum sergilemesinden kaynaklanıyor olabilir. Erözkan [9], ilköğretim 
sekizinci sınıf öğrencilerinde çok yönlü hiyerarşik regresyon analizi yöntemi ile cinsiyet, sosyoekonomik düzey, ana ve baba eğitim düzeylerinin depresyona özgün katkısının olmadığ1 sonucuna varmış, bunların yerine ebeveyn tutumları, benlik sayg1s1, mükemmelliyetçilik ve sınav kaygısının ise depresyonun önemli belirteci olduğunu saptamıştır.

Eskin ve ark. [27] lise öğrencilerinde yaptıkları çalışmalarında öğrencilerin \%17,5'inin ÇDÖ’ye göre 19 ve üzerinde puan aldığını ve oranın kızlarda daha yüksek olduğunu tespit etmişlerdir. $\mathrm{Bu}$ çalışma sonucunda lise öğrencisi ergenler arasında depresyonun yaygın olabileceği kanısına varmışlar ve bulgularının kendine güveni az, sosyal ilişkileri zayıf ve yetersiz problem çözme beceri düzeyine sahip ergenlerin ve akademik başarı sorunları yaşayan erkek ve eğitim seviyesi düşük babası olan kızların depresyon açısından risk altında olduğuna işaret ettiğini bildirmişlerdir. $\mathrm{Bu}$ çalışmada özellikle ergenlik döneminin, depresyonun gelişimsel bir psikopatoloji olarak anlaşılması, sağaltımı ve önlenmesi için yapılabilecek girişim stratejilerinin oluşturulması açısından önemli olduğu vurgulanmış; ÇDÖ’den yüksek puan almanın bir klinik tanı olmadığı ve depresyonu olmanın dışındaki bir takım nedenlerle bazı çocukların bu düzeyde bir puan almış olabileceğinin göz önünde bulundurulması gerektiğine dikkat çekilmiştir. Çorum'un Karg1 ilçesinde 12-17 yaş arasındaki çocuklarda yapılan özsayg1 ve depresyon taramasinda ortalama depresyon ölçeği puanı 13,3 7,3 olarak bulunmuştur. Depresyon puanları yükseldikçe özsaygı puanlarının azaldığg 1 görülmüştür. Aynı çalışmada ebeveynlerin öğrenim düzeyinin yüksekliği, demokrat aile yapısına sahip olma ve vücut ağırlığından memnun olmanın depresyon puanını azalttığı; ekonomik durumu kötü algılama, baskıcı aile tutumu, kötü arkadaşlık ilişskileri, sağlık durumunu kötü algılamanın depresyon puanını yükselttiği bildirilmiştir [28].

Ertekin Pınar ve Tel [29], 4.-7. Sinıf öğrencilerinde ÇDÖ puanını 9-11 yaş arasında \%7,8; 1214 yaş arasında da \%6,2 oranında 19 ve üstünde saptamışlardır. Üniversite mezunu ebeveynlerin çocuklarında puan ortalamasının düşük olduğunu, ev hanımlarının çocuklarında ise yüksek olduğunu tespit etmişlerdir. Okul başarısını yüksek algılayanlarda, okul dışında arkadaşı olduğunu belirtenlerde puan ortalaması düşük bulunmuştur. Sosyal destek puanları arttıkça depresyon belirti puanlarının azaldığının tespiti ve çocukların depresyon düzeylerinin düşük olmasında ebeveynlerin eğitim ve mesleğinin rol oynadığının görülmesi önem arz etmektedir. Demir ve ark. [30] ergenlerde depresif bozukluğu incelemişler ve yapılandırılmış formlar kullanılarak yapılan çalışmalarda öz bildirime dayalı ölçeklerle olduğundan daha düşük oranda, ayrıca klinik muayene ile, yapılandırılmış görüşmelerle olduğundan daha az oranda tanı konulduğunu belirtmişlerdir. Herhangi bir depresif bozukluğu olan ergenlerin oranının $\% 4,3$ olarak belirlendiği, majör depresif bozukluğun yaygınlığının $\% 3$, distimik bozukluğun yaygınlığının ise \%1,3 olduğunu bildirmişlerdir. Ayrica, aile üyelerinde kronik fiziksel hastalık bulunması olasılığının da kontrol grubundaki yaşıtlarına göre daha yüksek olduğunun saptandığ üzerinde durmuşlardır. Her ne kadar ebeveyn depresyonunun çocuklarda medikal ve psikiyatrik durumları genel olarak arttırdığ 1 bilinse de, bunun depresyona özgünlüğü gösterilememiştir [8].

İran'da ergenler üzerinde yapılmış tarama çalışmalarında da oranlar oldukça yüksek saptanmıştır. Kaşan kentinde 509 kız lise öğrencisinde Beck Depresyon Ölçeği ile kızların \%53,3'ünün deprese olduğu ve depresif düzeyle psikososyal ihtiyaç memnuniyeti arasında anlamlı düzeyde direkt ilişki olduğu saptanmış; ergenlerde ailelerin çocuklarının psikososyal ihtiyaçlarına önem vermesinin depresyonu azaltabileceği belirtilmiştir [31]. Yine $762 \mathrm{k} 1 \mathrm{z}$ lise öğrencisinde Beck Depresyon Ölçeği ile yap1lan taramada kızların \%53,4'ünün depresif olduğu ve depresyonla anne eğitimi, ebeveyn mesleği, kardeş sayısı, baba yaşı arasında ilişki bulunmadığ1 saptanmış; baba eğitimi arttıkça depresyon düzeyinin azaldığ 1 belirtilmiştir [32]. İran'da yapılan başka bir çalışmada da 15-17 yaşındakilerin depresyon skoru daha fazla bulunmuştur ve kızların daha fazla depresif semptom gösterdiği tespit edilmiştir. S1k görülmesine rağmen depresyonun tanınmaması veya yanlış tanı konması nedeni ile profesyonel yardım alınmasının geciktiği vurgulanmıştır [33].

Avustralya'da yapılan bir çalışmada 10-14 yaş grubunda depresif semptomlar \%33 olarak tespit edilmiştir ve kızların oranı daha fazladır. Artmış fiziksel aktivite, daha az boş vakte sahip olma ve daha az televizyon izlemenin daha az depresif semptom göstermeyle ilişkili olduğu da vurgulanmıştır. So- 
nuçta çocukların fiziksel olarak daha aktif olmaya ve daha az televizyon-bilgisayarla ilgilenmeye yönlendirilmelerinin akıl sağlığına katkıda bulunacağ1na vurgu yapmışlardır [34]. Amerika' da yapılan bir çalışmada 12-18 yaş arasında depresif semptomlar $\% 0,2$ olarak tespit edilmiştir. Depresyonun yaygınlığının 1rk, etnik köken ve bölgesel değişimler gösterdiği saptanmıştır. Rutin depresyon taramasının yatkın çocukların saptanmasına neden olabileceği gibi tedaviye başlama zamanını da öne alabileceğinin üzerinde durulmuştur [35].

Depresyon oranlarının prepubertal dönemde kız ve erkeklerde benzer olduğu, erken ergenlikle birlikte kızlarda artış şeklinde bir cinsiyet farkının ortaya çıktığı belirtilmektedir. Biz cinsiyet fark1 saptamamış olsak da bazı çalışmalarda kız ergenlerin erkeklerden daha fazla sayıda ve daha ağır depresif belirti gösterdiği bildirilmiştir [36].

Fransa'da birinci basamağa başvuran çocuk ve adölesanlarda depresyon prevalansının araşt1rıldığı bir çalışmada 13 yaş altındakilerin \%10’undan fazlasında, 13 yaş üstündekilerin de $\% 5$ 'inde depresif bozukluk olduğu saptanmıştır. Depresyon skoru ne olursa olsun aile hekimine başvuruların \%50'sini somatik yakınmaların oluşturduğu görülmüş; ayrıca, depresyonların orta düzeyde olduğu, depresif adölesanların yarısında atipik depresyon olduğu, aile bağlılıği ve okul performasının veya ailesel psikiyatrik öykünün depresyon skorları ile ilgisinin olmadığı belirtilmiştir. Birinci basamağa başvurularda depresyonun tanısının $\% 70$ oranında konulamadığını tahmin ettiklerini bildirmişler ve birinci basamağa başvuran genç nüfusta depresif bozuklukların yüksek oranda bulunduğunun bilinmesinin psikiyatrik değerlendirme ve tedavi için sevki hızlandırabileceğini vurgulamışlardır [37]. Bhatia ve Bhatia [3] derlemelerinde 9-17 yaş grubunun \%5'inin major depresyon kriterini karşılad1ğını, adölesanların da \%3'ünde distimik bozukluk görüldügünü bildirmişlerdir. Birinci basamakta tüm çocuk ve adölesanların depresyon için rutin olarak taranmasının yararlı olup olmadığının açık olmadığını, kanıtların çocuklarda erken müdahale etmenin uzun dönem sonuçları iyileştirebildiğini gösterdiğini bildirmişlerdir.

Sonuç olarak farklı çalışmalarda çocuk ve ergenlerde depresif belirtilerin görülme sıklı̆̆ının $\% 0,2$ [35] ila \%99,2 [23] arasında değiştiği görül- müştür. $\mathrm{Bu}$ önemli fark, çalışmalarda kullanılan ölçütlerin, incelenen örneklemlerin, ülkelerin, sosyodemografik kültürel özelliklerin birbirinden fark11 olmasından kaynaklanmaktadır ki bütün bunlar duygudurumun çevresel koşullarla ne kadar bağlantılı olduğunu göstermektedir. Çalıșmamızdaki yüksek değer de bunlara bağlanmıştır ancak kontrollü çalışmalara ihtiyaç vardır. Depresif semptomlar hem çocuk hem de adölesanlarda normal sayılabilir çünkü pek çok toplum yetişkinlikten önce bir şekilde depresif semptomlar bildirmektedirler fakat tanı düzeyindeki depresif bozukluklar daha az sıklıkta görülürler. Lack ve Gren'in [14] belirttiği gibi birçok nedenden dolayı çocukta tam ve ayrıntılı bir değerlendirme yapmak zor olabilir, aksi davranışlar ve saldırganlık gibi dışa vurulan semptomlar ebeveynler ve öğretmenler tarafindan depresyon ve anksiyete gibi içsel problemlerden daha kolay gözlenir ve söylenir. $\mathrm{Bu}$ yüzden tanı için multimodal değerlendirme yöntemi kullanılarak bilgiler birçok kaynak ve metotla, çocukla beraber ebeveyn, bakıcı ve öğretmenlerden de alınmalı, ölçek kullanımı yanında tanısal görüşme teknikleri de uygulanmalıdır.

Bu bağlamda çocukların, özellikle de ergenlerin daha mutlu bir çocukluk geçirebilmeleri için çocuklara daha fazla sosyal ortam yaratılması (sinema, tiyatro, oyun alanlar1, parklar gibi), sürekli ve nitelikli ebeveyn, özellikle de anne-çocuk ilişkisi sağlanması konusunda ebeveynlerin eğitilmesi, çocuklara iletişim ve başa çıkma becerileri kazandırmaya ve geliştirmeye yönelik eğitimler (drama dersleri gibi) verilmesi çok önemlidir. Depresif bozuklukların daha erken tanınıp önlem alınabilmesi için de ailelerin bu konuda bilgilendirilip bilinçlendirilerek farkındalık oluşturulması, çocuk sorun yaşadığında kendini ifade etme becerisi verilmesi ve nereye başvuracağının öğretilmesi, okullardaki rehberlik hizmetlerine ağırlık verilmesi, psikolojik danışmanlık hizmetlerinin geliştirilip yaygınlaştırılması, birinci basamak hekimlerinin meslek içi eğitimlerle bilgilendirilmesi, ölçek taramaları ile riskli çocuk veya grupların belirlenmesi, riskli olan çocukların izlenmesi, tanıda tecrübeli multidisipliner bir ekip kullanılması gerekir.

Çocuklarda psikososyal faktörler incelenirken ebeveyn streslerinin, özellikle de işle ilgili olanların göz önünde bulundurulması gerekmektedir. Sağlıklı nesiller, ancak sağlıklı çocuklarla sağlanır. 


\section{KAYNAKLAR}

1. Depresyon Bozuklukları. Amerikan Psikiatri Birliği, Ruhsal Bozuklukların Tanısal ve Sayımsal Elkitabı, Beşinci Bask1 (DSM-5), Tanı Ölçütleri Başvuru Elkitabı'ndan Çev. Köroğlu E, Hekimler Yayın Birliği, Ankara, 2013, sayfa:91-112.

2. Hamrin V, Pachler MC. Child \& adolescent depression: review of the latest evidence-based treatments. J Psychosoc Nurs Ment Health Serv 2005;43:54-63.

3. Bhatia SK, Bhatia SC. Childhood and adolescent depression. Am Fam Physician 2007 Jan 1;75:73-80.

4. www.who.int/mental_health (Erişim Tarihi: 29.12.2014)

5. Allgaier AK, Krick K, Opitz A, et al. Improving early detection of childhood depression in mental health care: the Children's Depression Screener (child-S). Psychiatry Res 2014;217:248-52. Doi: 10.1016/j.psychres.2014.03.037. Epub 2014 Apr 5.

6. Purper-Quakil D, Michel G, Mouren-Siméoni MC. Vulnerability to depression in children and adolescents: update and perspectives. Encephale 2002;28:234-40.

7. Toros F. Çocukluk çağ 1 ve ergenlik dönemi depresyonlarında risk etmenleri. T Klin Psikiatri 2002;3:75-79.

8. Tamar M, Özbaran B. Çocuk ve ergenlerde depresyon. Klinik Psikiyatri 2004;2:84-92.

9. Erözkan A. İlköğretim sekizinci sınıf öğrencilerinde depresyonun yordayıcıları. İlköğretim Online 2009;8:334-345. [Online]:http://ilkogretim-online.org.tr

10. Boutelle K, Eisenberg ME, Gregory ML, Neumark-Sztainer D. The reciprocal relationship between parent-child connectedness and adolescent emotional functioning over 5 years. J Psychosom Res 2009;66:309-316. Doi: 10.1016/j. jpsychores.2008.10.019. Epub 2009 Jan 16.

11. Çetin H, Çok F. Ana babaların ergen çocuklarını izlemeleri: bir gözden geçirme. Çocuk ve Gençlik Ruh Sağlığı Dergisi 2011;18:223-234.

12. Kovacs M. Rating scales to assess depression in school-age children. Acta Paedopsychatr 1981; 46:305-315.

13. Öy B. Çocuklar için depresyon ölçeği: Geçerlik ve güvenirlik çalışması. Türk Psikiyatr Derg 1991;2:132-137.

14. Lack CW, Gren AL. Mood disorders in children and adolescents. Journal of Pediatric Nurses 2009;24:13-25.

15. Agerup T, Lydersen S, Wallander J, Sund AM. Maternal and paternal psychosocial risk factors for clinical depression in a Norwegian community sample of adolescents. Nord J Psychiatry 2015 Jan;69:35-41. doi: 10.3109/08039488.2014.919021. Epub 2014 May 21.

16. Heinrich CJ. Parents' employment and children's wellbeing. Future Child 2014;24:121-46.

17. Eichler AK, Glaubitz KA, Hartmann LC, Spangler G. Assessment of parental stress using the "Eltern-BelastungsScreening zur Kindeswohlgefährdung” (EBSK) - association with emotional and behavioral problems inchildren. Z Kinder Jugendpsychiatr Psychother 2014;42:213-22. doi: 10.1024/1422-4917/a000294.

18. Spijkers W, Jansen DE, Reijneveld SA. Parental internalizing problems in a community sample: association with child psychosocialproblems. Eur J Public Health 2014 Feb;24:11-5. doi: 10.1093/eurpub/ckt037.

19. Kim HH, Viner-Brown SI, Garcia J. Children's mental health and family functioning in Rhode Island. Pediatrics 2007;119:22-8.

20. Johnson RC, Allen TD. Examining the links between employed mothers' work characteristics, physical activity, and child health. J Appl Psychol 2013;98:148-57. doi: 10.1037/ a0030460.

21. Çetinkaya F. Örgütlerde stres kaynaklarının çalışanların iş-aile çatışması üzerindeki etkisi ve Afyon il merkezindeki bayan banka çalışanları üzerine bir araştırma. Afyon Kocatepe Üniversitesi, Sosyal Bilimler Enstitüsü, İşletme AD Yüksek Lisans Tez Çalışması. Haziran 2011. Ulaşılabileceği adres: http://www.aku.edu.tr/AKU/DosyaYonetimi/ SOSYALBILENS/tezler/isletme/0606/0125.pdf

22. Yıldırmalp S, Öner M, Yenihan B. Hemşirelerin iş-aile çatışması ve yaşam tatmini düzeyleri: Demografik özellikler açısından bir değerlendirme. Siyaset, Ekonomi ve Yönetim Araştırmaları Dergisi 2014;2:165-182.

23. Ocakcı A, Kürtüncü M. Çocuk yuvasında yaşayan 9-13 yaş grubu çocuklarda depresyon ve benlik kavramı düzeylerinin belirlenmesi. Eğitim Bilimleri ve Uygulama Dergisi 2004;3:75-86.

24. Ceylan A, Özen Ş, Palancı Y, et al. Anadolu Psikiyatri Dergisi 2003;4:144-150.

25. Kars V, Arslan N, Erik L, ve ark. Lise son sınıf öğrencilerinin meslek seçiminde karşılaştı̆̆ 1 sorunlar ve bu sorunların anksiyete ve depresyonla ilişkisi. Dicle Med J 2014;41:187190. Doi: 10.5798/diclemedj.0921.2014.01.0396

26. Ören N, Gençdoğan B. Lise öğrencilerinin depresyon düzeylerinin bazı değişkenlere göre incelenmesi. Kastamonu Eğitim Dergisi Mart 2007;15:85-92.

27. Eskin M, Ertekin K, Harlak H, Dereboy Ç. Lise öğrencisi ergenlerde depresyonun yaygınlığ 1 ve ilişkili olduğu etmenler. Türk Psikiatri Dergisi 2008;19:382-389.

28. Yılmazel G, Günay O. Çorum ili Kargı ilçesinde öğrenim gören 12-17 yaş arasındaki öğrencilerde özsayg1 ve depresyon. Sağlık Bilimleri Dergisi 2012;21:20-29.

29. Ertekin Pınar Ș, Tel H. İlköğretim 4.-7. Sınıf öğrencilerinin depresyon düzeyleri ile sosyal destek algıları arasındak ilişki. Çocuk ve Gençlik Ruh Sağlığı Dergisi 2012;19:6980 .

30. Demir T, Eralp Demir D, Kayaalp ML, Büyükkal B. Ergenlerde depresif bozuklukların yaygınlığı ve depresif bozukluğu olan ergenlerin özellikleri. Çocuk ve Gençlik Ruh Sağlığı Dergisi 1999;6:3-11.

31. Sooky Z, Sharifi KH, Tagharrobi Z. The depression prevalence and psychosocial need satisfaction in teenagers. European Psychiatry-Abstract for poster sessions. 2007;22:p135,s260.

32. Sooky Z, Sharifi KH, Tagharrobi Z. The depression prevalence and its related factors in teenagers in Kashan-Iran 2006. European Psychiatry-Abstract for poster sessions. 2007;22:p86,s246.

33. Essau CA, Olaya B, Pasha G, et al. Depressive symptoms among children and adolescents in Iran: a confirmatory fac- 
tor analytic study of the centre for epidemiological studies depression scale for children. Child Psychiatry Hum Dev 2013;44:123-136. Doi: 10.1007/s10578-012-0314-1.

34. Kremer P, Elshaug C, Leslie E, et al. Physical activity, leisure-time screen use and depression among children and young adolescents. J Sci Med Sport 2014;17:183-187. Doi: 10.1016/j.jsams.2013.03.012. Epub 2013 May 3.

35. Zenlea IS, Milliren CE, Mednick L, Rhodes ET. Depression screening in adolescents in the United States: a national study of ambulatory office-based practice. Acad Pediatr 2014;14:186-191. Doi: 10.1016/j.acap.2013.11.006.

36. Takakura M, Sakihara S. Gender differences in the association between psychosocial factors and depressive symptoms in Japanese junior highschool students. J Epidemiol 2000;10:383-391.

37. Mathet F, Martin-Guehl C, Maurice-Tison S, Bouvard MP. Prevalence of depressive disorders in children and adolescents attending primary care. A survey with the Aquitaine Sentinelle Network. Encephale 2003;29:391-400. 